\title{
SHORT LEGAL FORAY ON THE EUROPEAN CERTIFICATE OF SUCCESSION
}

\section{Veronica STOICA}

\author{
V. Stoica, G. Dumitrache
}

\author{
"Alexandru Ioan Cuza" Police Academy, Romania \\ *Corespondence: Veronica Stoica, 1A Privighetorilor Alley, Bucharest, Romania, \\ E-mail: verostoica@yahoo.com
}

\section{Gabriela DUMITRACHE}

Notary public, Bucharest Chamber of Notaries Public, Romania

*Corespondence: Gabriela Dumitrache, 1A Privighetorilor Alley, Bucharest, Romania

E-mail: gabriela.dumitrache.ene@gmail.com

\begin{abstract}
The structure and content of the article describe the considerations relating to the premises of the European Heir Certificate, the juridical concept, character, purpose and not only the probative value and effects of this European document in the light of Romanian and international specialized literature, but also from the point of view of notarial practice.
\end{abstract}

KEYWORDS: European Certificate of Succession, Regulation, probative value, effects.

\section{INTRODUCTION}

The increase of the international inheritance due to the growing international mobility of persons and capital was the reason why the European legislator conceived EU Regulation No. $650 / 2012$, whose aims are to facilitate the settlement of inheritance with foreign elements. These rules adopted at European level are purposeful reduction of legal difficulties arising in the event of death of a person who owns property in another EU Member State. The major innovation of the creation of a European Heir Certificate appears from well defined goal of proving the status of heir, legatee and the duties of executor or administrator of the inheritance into another Member State.

\section{THE PREMISES OF THE EUROPEAN CERTIFICATE OF SUCCESSION CONSECRATION(ECS)}

Over the years, internationally supported efforts were undertaken in order to harmonize the right of inheritance ${ }^{1}$ and countless legal instruments adopted in this endeavor. We recall, in this regard, the Hague Conference on Private International Law, an organization established precisely which came into being for the purpose of harmonizing the rules of private international law worldwide.

The Hague Conference on Private International Law has devoted an important part of its concerns to issues raised/specified by the regulation of cross-border succession through four reference documents ${ }^{2}$ :

- Convention of 5 October 1961 on the Conflicts of Laws Relating to the Form of Testamentary Disposition

\footnotetext{
${ }^{1}$ http://ec.europa.eu/civiljustice/applicable_law/applicable_law_int_ro.htm, consultat la 20 septembrie 2017

${ }^{2}$ For more details see Mariel Revillard, Drept Internațional Privat și Comunitar. Practică Notarială. Prefață de Paul Lagarde. Ediția a 6-a, Editura Notarom, 2009, pag. 240-244
} 
- Convention of 2 October 1973 Concerning the International Administration of the Estates of Deceased Persons

- Convention of 1 July 1985 on the Law Applicable to Trusts and on their Recognition

- Convention of 1 August 1989 on the Law Applicable to Succession to the Estates of Deceased Persons

The idea of the EMS's consecration was inspired, apparently, by the Convention of 2 October 1973 concerning the International Administration of the Estates of Deceased Persons. The signatories to this convention ${ }^{3}$ established a common denominator in identifying a unit of inheritance law to give the parties involved predictability in the succession realm. The merit of the Convention is to adopt the principle of unity of succession law $^{4}$ and the professio juris consecration ${ }^{5}$, relevant aspects in the planning of a succession with elements of foreignness. This convention has attempted to solve some difficulties of international successions by establishing an "international certificate designating the person empowered to manage the succession by indicating its powers".

According to the Convention, this certificate should have been drawn by the authorities and, in principle, under the domestic law of the last ordinary residence of the deceased. ${ }^{6}$

The aim established by the European Union to promote and develop an area of freedom, security and justice based on the free movement of persons could not neglect the difficulties caused by international successions. They wished to ensure greater predictability in establishing the court or competent authority to solve the inheritance, but also in determining the law applicable to it, thus establishing effective tools for organizing an inheritance.

On this line, the European Council adopted on 4-5 November, in Bruxelles ,"The Hague Program" regarding to strengthening freedom, security and justice in the European Union, which highlights the usefulness of adopting an instrument at European level aimed at unifying the conflicting rules in the area of inheritance law, including rules of international competence in this field, guaranteeing mutual recognition and enforcement of inheritance decisions and the establishment of a European Certificate of Succession. ${ }^{7}$ In addition, the European Council meeting in Brussels on 10-11 December 2009 adopted a new multiannual program entitled "The Stockholm Program - An open and secure Europe serving and protecting the citizens", highlighting the need to extend the principle of mutual recognition to new areas , essential for everyday life, such as successions and wills. This was the basis for a proposed future regulation that would maintain the traditions of the country's legislation in this area and would provide increased predictability to those interested in anticipating succession planning.

The European Commission published on 1 March 2005 the Green Card "Succession and wills", which is a questionnaire containing questions on conflicting rules in the field of succession, including the rules of international competence which was to be taken into consideration when adopting a future European instrument in this area. This questionnaire also contains questions on EMS, on the conditions for its release, its content and its legal effects. The responses to the Green Paper were published on the website of the DirectorateGeneral for Justice, Freedom and Security. ${ }^{8}$

\footnotetext{
${ }^{3}$ The Hague Convention of 2 October 1973 entered into force on 1 July 1993 between Portugal, the Slovak Republic and the Czech Republic. It was signed by Italy, the Netherlands, Luxembourg, the United Kingdom and Turkey.

${ }^{4}$ Based on this principle, the only law governs the movable and immovable property succession

5 The testator's ability to choose the law applicable to his succession.

${ }^{6}$ For more details see Mariel Revillard,, pg.288

${ }^{7}$ For more details see articles (5) şi (6) the preamble to the EU Regulation no. 650/2012 of the European Parliament and of the Council on jurisdiction, applicable law, the recognition and enforcement of judgments and the acceptance and enforcement of authentic instruments in matters of succession and on the creation of a European Certificate of Succession.

${ }^{8}$ http://ec.europa.eu/justice/index_en.htm\#newsroom-tab consultat la 20 septembrie 2017.
} 


\section{SHORT LEGAL FORAY ON THE EUROPEAN CERTIFICATE OF SUCCESSION}

At the request of the European Commission - Directorate-General for Justice and Home Affairs, the German Notary Institute, ${ }^{9}$ together with Professors Heinrich Dörner (University of Münster) and Paul Lagarde (Sorbonne University), developed a large study of comparative law and private international law in inheritance matters - "Etude de droit compartit sur les règles de conflits de juridictions et de conflits de lois relatives et testaments et successions dans les Membres de l'Union européenne". The study was based on 15 national reports, including the final synthesis report and conclusions, under the coordination of the two illustrious teachers. ${ }^{10}$

Proposal for a Regulation of the European Parliament and of the Council on jurisdiction, applicable law, recognition and enforcement of decisions and authentic instruments in matters of succession and the creation of a European Certificate of Succession, was launched in October 2009. Max Planck Institute for Comparative and International Private Law în Hamburg $^{11}$ has developed a detailed commentary on the articles of this draft, containing proposals for amendment or modification, entitled "Comments on the European Commission's Proposal for a Regulation of the European Parliament and of the Council on jurisdiction, applicable law, recognition and enforcement of decisions and authentic instruments in matters of succession and the creation of a European Certificate of Succession"12. The study was published in "Rabels Zeitschrift für ausländisches und internationales Privatrecht", vol. 74 (2010), Heft 3 (Juli), p. 522-720.

Regulation (EU) No 650/2012 of the European Parliament, applicable law, recognition and enforcement of decisions and acceptance and enforcement of authentic instruments in matters of succession and on the creation of a European Certificate of Succession was adopted on 4 July 2012 and was published on 27 July 2012 in Official Journal of the EU no. 201.

Regulation (EU) No 650/2012 is to apply to the succession of persons who have died since August 17, 2015, stating the possibility of choosing the law applicable to the inheritance just before that date under Art. 83 - Transitional provisions ${ }^{13}$.

Starting in 2012, EU Member States have had a three-year deadline to harmonize their national legislation so that the new EU rules produce legal effects.

EU Commissioner for Justice, Ms. Viviane Reding, Vice-President of the Commission, said: "Once we have relieved the situation of couples involved in cross-border divorce, we are doing the same thing for families that have to cope with the legal consequences of losing a close person." In this context, "the existence in each EU Member State of distinct rules on successions has frequently resulted in a legal labyrinth. This legislation simplifies procedures

\footnotetext{
${ }^{9}$ DeutschesNotariatinstitut - DnotI.

10 For more details seehttp://ec.europa.eu/civiljustice/publications/docs/testaments_successions_fr.pdf; http://dnoti.de/ (ambele site-uri consultate la 20 septembrie 2017); D.A. Popescu, Ghid de drept internațional privat în materia succesiunilor, Ed. Magic Print, Onești, 2014, pag.8; D.A. Popescu, Dreptul european al moștenirilor sau cum să traversezi râul simțind pietrele. Dreptul succesoral între trauma tradiției și perspectiva modernității. Principiile regulamentului european al succesiunilor în Revista Română de Drept Privat nr. 1/2014, pag. 151

${ }^{11}$ Institut für Ausländisches und Internationales Privatrecht

12 http://europarl.europa.eu/document/activities/cont/201005/20100526ATT75035/20100526ATT75035EN.pdf consultat la 21 septembrie 2017

13 "(1) This Regulation shall apply to the succession of persons who died on or after 17 August 2015.

(2) If the deceased has chosen the law applicable to his succession before 17 August 2015, that choice is valid if he fulfills the conditions laid down in Chapter III or is valid in applying the rules of private international law in force at the time of the election the state in which the deceased was habitually resident or in any of the States whose citizenship it had.

(3) A provision for death toll made before 17 August 2015 is admissible and valid on the merits of the form if it satisfies the conditions laid down in Chapter III or is admissible and valid on the merits and in the form of application of the rules of private international law which were in force in the Member State in which the deceased was habitually resident or in any of the States of which he or she is a national, or in the Member State in which the successor authority is situated.

(4) Where a death sentence was made before 17 August 2015 in accordance with the law which the deceased could have chosen under this Regulation, that law shall be deemed to be the law applicable to the succession."
} 
and citizens enjoy legal security. The enactment of this EU law facilitates the indentification of the law that will be applied in each case. This is just an example of how the European Union is working to resolve everyday legal issues and allow Europeans to make savings." ${ }^{14}$

\section{EUROPEAN CERTIFICATE OF SUCCESSION- CONCEPT, LEGAL CHARACTERS, PURPOSE AND PROBATIVE VALUE}

\section{II.1 CONCEPT}

One of the innovative elements of EU Regulation no. 650/2012 is the establishment of a European Certificate of Succession (EMS).

The main articles are Art.62 $2^{15}$, art.63 $63^{16}$ and Recital $67^{17}$ din of EU Regulation No. 650 / 2012.The argument behind the creation of this new European legal instrument starts from the EU desiderate expressed in the preamble of EU Regulation no. 650/2012 at recital 67, according to which: "In order for a succession with extraneous elements in the Union to be resolved in a rapid manner, the heirs, legatees, executors or administrators of succession assets should be able to easily prove their status and / or rights and competences in another Member State, for example in a Member State where the succession assets are located".

We note that the procedure has a precedent in the economy of European regulations, in the field of marriage dissolution, a European Certificate of Divorce was established by the provisions of Regulation (EC) no. 2201/2003.

EMS is issued for the well-determined purpose of being used in another Member State.

We note that the European legislator does not provide a legal EMF definition, and the legal literature has the task of defining the concept introduced by EU Regulation no. 650/2012. The doctrine ${ }^{18}$ outlined a definition according to which "the European Certificate of Succession is the act issued by a competent authority through which heirs, legatees, testamentary executors and administrators of the patrimony of the person whose inheritance is transmitted can prove their quality and rights in an another EU Member State in the case of inheritances opened as from 17 August 2015". The European Certificate of Succession was also defined as "a

\footnotetext{
$14 \mathrm{https} / / /$ legestart.ro/normele-ue-de-simplificare-a-succesiunilor-transfrontaliere-au-in-prezent-putere-de-lege/ consultat la 21 septembrie 2017

15 "(1). This Regulation establishes a European Certificate of Succession (hereinafter referred to as "the Certificate"), which is issued for use in another Member State and produces the effects listed in Article 69.

(2) The use of the certificate is not mandatory.

(3) The certificate does not replace internal documents used for similar purposes in the Member States. However, a certificate issued for use in another Member State shall produce the effects listed in Article 69 and in the Member State whose authorities have issued the certificate under this Chapter.

16 (1) The certificate is intended for use by heirs by direct liaison with successors and by executors or administrators of inheritance property which must prove their status in another Member State or exercise that right as heir or legatee and / or the duties of the executor or the successor inheritor

(2) The certificate may be used in particular to prove one or more of the following:

(a) the status and / or the rights of each heir or, where applicable, of each legatee mentioned in the certificate and the respective shares in the succession heritage;

(b) the assignment of a good or certain property that is part of the succession heritage to the heir / heirs or, as the case may be, to the said legatee (s) mentioned in the certificate

(c) the attributions of the person mentioned in the certificate as the executor of the testamentary or as the administrator of the succession patrimony.

17 "In order for a succession with extraneous elements in the Union to be resolved in a rapid, simple and effective manner, the heirs, legatees, testamentary executors or administrators of the succession heritage should be able to easily prove their status and / or rights and competences in - in another Member State, for example in a Member State where the succession goods are located. To enable this, this Regulation should provide for the creation of a uniform certificate, the European Certificate of Succession (hereinafter referred to as the Certificate) be issued for use in another Member State. In order to comply with the principle of subsidiarity, the certificate should not replace the internal documents that may exist for similar purposes in the Member States."

${ }^{18}$ To be seen Veronica Stoica, Succinte considerații în legătură cu certificatul european de moștenitor, Revista de investigare a criminalităţii, Vol. IX, nr. 1/ianuarie-iunie 2016, Ed. Universul Juridic, Bucharest, pag. 46
} 


\section{SHORT LEGAL FORAY ON THE EUROPEAN CERTIFICATE OF SUCCESSION}

uniform European document by means of which, in a Member State other than the issuing of the certificate, the rights of heirs, legatees, testamentary executors or administrators of the succession heritage, serves at the same time to exercise those rights". ${ }^{19}$

In another form ${ }^{20}$ "the European Certificate of Succession is a standard form intended to enable heirs, legatees, testamentary executors or successors to prove their quality and rights in successions from August 17, 2015".

We note that it is necessary to distinguish between the EMS, which is a standard form, with probative valences, and other documents issued in inheritance proceedings in the Member States, namely: "authentic act", "judgment" or "judicial transaction" as defined by EU Regulation no. 650/2012 in Article 3, paragraph 1. ${ }^{21}$

\section{II.2 THE OPTIONAL CHARACTER}

As a rule, the application and use of ECS is not mandatory. EU Regulation no. 650/2012 enshrines in his head note on the point67, the principle of EMS subsidiarity, in the light of which it "does not replace domestic documents used for similar purposes in the Member States"22.

The effect of this principle lies in the fact that ECS can circulate alongside national certificates of succession or other internal documents used for similar cross-border successions (being excluded a substitution thereof) or including states where the succession procedure completes with issuing such a certificate ${ }^{23}$.

If we analyze the optional character of EMS from the perspective of notary practice in Romania, we identify the possibility that in an international succession, according to the request of the heirs, a notary issues both a certificate of heir under the Law no. 36/1995 of the notaries public and of the activity notaries in Romania, as well as an EMS under Art.67 of the EU Regulation no. 650/2012 24 .

Also, legal literature ${ }^{25}$ outlining the event that a foreign element, which justifies the issuance of ECS, is not present since the opening date of succession, but appears later. In this case, it is possible to issue an ECS in an inheritance file that already issued a national certificate of inheritance.

\footnotetext{
${ }^{19}$ For more details see Daniela Negrilă, Moștenirea în noul Cod civil. Studii teoretice și practice. Ediția a II-a, revăzutăși readăugită, Ed. Universul Juridic, Bucharest, 2015, pag. 324

${ }^{20}$ For more details see D.A. Popescu, Ghid, op. cit., pag. 101

21 "(i) 'Authentic instrument' means a document in matters of succession drawn up or registered formally as authentic instrument in a Member State and the authenticity of which:

(i) refers to the signature and content of the authentic instrument; and

(ii) has been drawn up by a public authority or by any authority empowered to do so by the Member State of origin.

(h) "legal transaction" means a transaction in matters of succession approved by a court or entered into before a court in the course of proceedings;

(g) "judgment" means any judgment on matters of succession rendered by a court of a Member State, whatever its name, including a decision on the determination by a Registrar of the costs;

22 The principle of ECS subsidiarity is reiterated in paragraph 3 of Article 62 of the Regulation.

${ }^{23}$ For example in the case of Italy.

24 "Issuing the certificate:

1. The issuing authority shall, without delay, issue the certificate in accordance with the procedure laid down in this Chapter where the elements to be certified have been determined in accordance with the law applicable to the succession or any other law applicable to particular elements. It shall use the form drawn up in accordance with the consultation procedure referred to in Article 81 (2).

The issuing authority shall not issue the certificate, in particular if:

(a) the elements to be certified are the subject of a challenge; or

(b) the certificate would not be in conformity with a judgment relating to the same elements.

2. The issuing authority shall take all necessary measures to inform the beneficiaries of the issue of the certificate."

${ }^{25}$ To be seen Ioana Olaru, Dreptul european al succesiunilor internaționale, Ghid practic, Editura Notarom, Bucharest, 2014, page 153 and Daniela Negrilă, op. cit., page 323
} 
It can be seen that Regulation (EU) No 650/2012 does not fully clarify the relationship between ECS and national certificate of succession. Therefore the European legislator is silent which of these would take precedence in the event of a conflict ${ }^{26}$ or what procedure should be followed when they were required simultaneously different State authorities for their issue ${ }^{27}$. It seems that it falls to the European Court of Justice to clarify the gaps in Regulation (EU) No 650/2012 which can lead to legal uncertainty.

\section{II.3 THE PURPOSE OF ECS}

ECS purpose is clearly stated in Article 63 paragraph 1, which is a legal instrument used by heirs, the legatees having direct rights in the succession and the executors or administrators of the estate who need to prove their status in another Member State or to exercise that right of a heir or legatees and/or those duties of an executor or administrator of the estate.

It can be seen that ECS covers all certificate types regulated in the Romanian law, respectively the certificate which confirm the quality of the executor or as heir. Also, as we will show below, it may be useful to other stakeholders, such as creditors surviving spouse or heirs.

\section{II.4 PROBATIVE VALUE}

ECS is a document that can be issued in all succession proceedings with foreign elements and serves to prove the status as heir, legatee and the competences of the executors of wills or administrators of the estate in another Member State.

For example, we can remember the following assumptions which requires issuance of an ECS:

- when the last habitual residence of the deceased lies in another state;

- when goods constituting the estate are located in another country than the issuer.

Therefore, in an international succession ECS issue it is not mandatory ${ }^{28}$. Depending on the request of the parties to complete the procedure of succession, the notary will issue a national certificate of inheritance or will issue an ECS, if the parties wish proving certain rights in another Member State.

ECS can be used as evidence to prove the following issues listed by the Regulation (EU) No 650/2012 Article 63, paragraph 2:

"(a) status and / or rights of each heir or, as the case may be, each legatee mentioned in certificate and respective shares of the estate;

(b) the award of a specific asset or specific assets forming part of the estate of heir/heirs or, where appropriate, legatee mentioned (legatees mentioned) in the certificate;

(c) the powers of the person mentioned in the Certificate to execute the will or administer the estate."

For the first time, because of ECS there is a uniform sample, in particular the quality of heir/legatee, and the quality of the executor ${ }^{29}$. It can be seen that national certificates of succession are not replaced by this certificate.

In terms of probation, ECS creates a presumption of accuracy of the elements established by law that the certificate contains. The probative value of ECS lies in Article 69 paragraph 2 of

\footnotetext{
${ }^{26}$ In the sense that this priority should be recognized to the European certificate, to be seen P. Lagarde, "Les principes de bases du nouveau règlement européen sur les successions" RCDIP, no. 4/2012, page 72. In the sense that in Romania should prevail the national certificate of inheritance, which is authentic, to be seen Ioana Olaru, Dreptul european al succesiunilor internaționale, Ghid practic, Editura Notarom, Bucharest, 2014, page 154, apud D.A. Popescu, Ghid..., op. cit., note 251

27 The guidance of the doctrine of using the provisions of the institution of lispendence, although effective, can not completely prevent contradictory documents, see P. Wautelet, Article 62, Le droit européen des successions. Commentaire du Règlement no. 650/2012 du 4 juillet 2012, Bruylant, 2013, pag.717 apud D.A. Popescu, Guide ..., op. cit., Note 252

${ }^{28}$ To be seen Ioana Olaru, op. cit., page 154

${ }^{29}$ To be seen C. Dorsel, "Remarquessur le certificate succesoral européen", Europe For Notaries - Notaries For Europe, Training 2015-2017, JUST/2014/JTRA, pag.73
} 
the Regulation: "It is alleged that the certificate proves exactly the requirements set under the law applicable to the succession or under any other law applicable to specific elements. It is assumed that the person mentioned in the Certificate as the heir, legatee, executor or administrator of the estate is mentioned in the certificate status and/or to hold the rights or the powers stated in the certificate with no other conditions and/or restrictions attached to those rights or powers than those stated in the certificate."

We are therefore in the presence of a relative presumption which can be reversed by proving otherwise. ${ }^{30}$

\section{THE EFFECTS OF THE EUROPEAN CERTIFICATE OF SUCCESSION}

ECS content has a relative presumption of precision ${ }^{3132}$. This way, according to Article 69 of the Regulation, ECS is deemed to certify the veracity of the items referred in its content, proving "exactly the requirements set under the law applicable to the succession or under any other law applicable to specific elements."

ECS is automatically efficacious in all Member States (including the issuing State) without the need for any procedure of recognition / enforcement in the State of destination.

Therefore, in order to be accepted, the ECS effects does not require legalization or other similar formality, as it is been stipulated in Article 74 of the Regulation ${ }^{33}$. Also, ECS control in the destination country is not allowed. It can be seen, also as a consequence of its effectiveness, that the ECS can be challenged only in the Member State of origin. ${ }^{34}$.

The ECS effects stated in the Article 69 of the Regulation have basically a probative character and mainly refers the elements determined according to the lex successions (designation successors / legatees and their rights, the establishment of the administrator functions or of the executor). ECS effects could even concern matters which are governed by their own laws, but which also directly influences the content of the certificate (ex. The validity conditions of a disposition of property upon death) ${ }^{35}$.

People mentioned in the ECS are presumed to have the quality of legal heir, legatee, administrator or executor of the estate and they have the status and rights / powers recorded in the certificate. The person registered as beneficiary of the ECS can make use of this capacity, without any other documents or additional tests ${ }^{36}$. It can be seen that the presumption stated by ECS involves a reversal of the burden of proof which benefits to the person listed as the beneficiary in the certificate ${ }^{37}$.

We note that the European legislator provides legal protection to third parties who acted based on ECS. This way, bona fide third parties taking part in contractual relations with the heirs are entitled to acquire goods or to transfer to the heirs' goods or money, considering their quality emanating from ECS.

\footnotetext{
${ }^{30}$ Given the possibility of challenging the certificate (and correlatively, withdrawing, correcting or modifying it), the presumption can only be a simple one - to be seen R. Crône, "Le certificat successoral européen", in G. Khairallah, M. Revillard (dir.), Droit européen des successions internationales. Le règlement du 4 juillet 2012 , Defrénois, Lextenso, 2013, n 422, p. 183, apud D.A Popescu, Ghid..., op. cit., nota 266.

${ }^{31}$ J. Gomes de Almeida, Le certificate successoral européen: Quelques questions, Europe For Notaries - Notaries For Europe, Training 2015-2017, JUST/2014/JTRA, pag.112

${ }^{32}$ For documents issued in a Member State in the context of this regulation is not necessary any legalization or other similar formal condition.

${ }^{33}$ To be seen article 71 and article 72 of Regulation (UE) No 650/2012

${ }^{34}$ To be seen D.A. Popescu, Ghid..., op. cit., page 104

${ }^{35}$ We take into consideration the identity and civil status documents such as birth or marriage certificates.

${ }^{36}$ J.Gomes de Almeida, op. cit., page 112

${ }^{37}$ For instance, third party was notified to declare an appeal against ECS and acted without knowing how it will be solved.
} 
Regulation (EU) No 650 / 2012 establishes the validity of transactions involving third parties, unless they know that the information contained in the certificate are contrary to reality or did not know this because of their serious negligence. ${ }^{38}$

We note that the rules of the Regulation (EU) No 650 / 2012 resort to the rule error communis facit jus, which can be removed only if the third part did not know the reality because of serious negligence ${ }^{39}$.

As a rule, any entity (ex: a bank) which deals with the transfer of goods or made payments on account of ECS is considered released from those obligations and cannot be ordered to a new payment. Also, the good faith third part purchaser who acquires an ownership / another right on an asset under an ECS is deemed to have contracted by a person who is entitled to dispose of succession property and can not be forced to return it or pay its value to the true owner. In conclusion, the effects of ECS ensure legal certainty for bona fide third parties.

ECS efficacy, according to the European legislator, means access to public records through this available document. According to paragraph 5 of Article 69 of the Regulation "shall constitute a valid certificate for the recording of succession property in the relevant register of a Member State, without prejudice to Article 1 (2) (k) and (1)." This means certain that ECS is a valid document for registration of transfer of succession property in the relevant registers of a Member State (land registers, commercial register, register for inventions or trademarks) ${ }^{40}$, without requiring a special procedure.

Although, it can be seen that this rule must be reconciled with that stated in Article 1 paragraph 2 lit. k) and 1$)^{41}$ which excludes from the scope of Regulation the matters regarding the nature of real rights issues and enrollments in public registers.

It can be considered that the relationship between ECS and lex rei sitae is determined by the scope of Regulation (EU) No $650 / 2012$ and, this way, we should not overlook recital $18^{42}$.

Therefore, it can be concluded that whenever public records of a Member State requires special conditions for documents under which is recorded creation, transfer or termination of real rights, such compliance is mandatory. The solution is justified by the intention of the European legislator to safeguard the requirements of national legislation ${ }^{43}$, with the immediate consequence that sometimes to refrain from establishing legal equivalence between ECS and documents required by national law of Member States.

In other words, if the public registers allow recording the documents without imposing special conditions, ECS will be scored as the basis for transmitting property in the light of Article 69 paragraph 5 of the Regulation.

For instance, the legal doctrine ${ }^{44}$ claims that an ECS is not sufficient in order to proceed to France to update land registers, where the ECS must be accompanied by a notary certification.

\footnotetext{
${ }^{38}$ To be seen Daniela Negrilă, op. cit., page 330

${ }^{39}$ To be seen D.A. Popescu, Ghid..., op. cit., page. 105

40" Are excluded from the scope of this Regulation:

(k) the nature of rights in rem, and

(1) any recording in a register of ownership of immovable or movable property, including the legal requirements for such recording, and effects of recording or failing to record such rights in a register."

41 "Requirements for enrollment in a register of a right in immovable or movable property should be excluded from the scope of this Regulation. Should therefore be the law of the Member State in which the register is kept (for immovable property, the lex reisitae) to be the one that sets the legal conditions and how they have performed registration and which authorities, such as cadastral offices or notaries, are responsible for verifying all the requirements and that the documentation presented or established is sufficient or contains the necessary information."

${ }^{42}$ We took into consideration the validity conditions of those documents, strictly regulated by the law.

43 .To be seen C. Dorsel, op. cit., page. 89

${ }^{4}$ According to the article 31 of the Regulation: where a person claims a real right to which he is entitled under the law applicable to succession, and the law of the Member State where the real right is invoked does not provide for the real right in question, that right shall adapt, where necessary and as far as possible, to the closest equivalent real right under the law of that State, taking into account the objectives and interests pursued by the specific real right and its effects.
} 
The situation is the opposite in Germany, where it is sufficient to submit the ECS to make changes in the land registry.

Article 1 paragraph 2 lit. k) and 1) of the Regulation leads us to make the following interpretation:

- remains the preserve of each EU Member State to determine which are real rights. Therefore, no real right referred in the ECS cannot be entered in the registers of another Member State unless it integrates numerus clausus of real rights enshrined in the legal system of that State. As an example, remember the case when ECS mentions a dismemberment of property unrecognized in the legal system of the State of destination, in which case it is usually advisable to adapt real rights ${ }^{45},{ }^{46}$, in order to not miss the ECS of juridical efficacy;

- each EU Member State is free to decide which of real rights and other rights, facts, legal statements can be entered in public registers and in what circumstances;

- is the prerogative of each Member State to determine the effects of recording / failing to record such rights in a public register or constitutive effects of enforceability or information ${ }^{47}$.

It can be considered that the State of destination may require documents certifying other issues necessary for the registration of that right mentioned in ECS referring to fiscal issues (certificates showing payment of taxes related to real or payment of registration fees) or documents certifying the title of the deceased on those goods. ${ }^{48}$

We note that the legal effects of ECS cannot be extended to matters excluded from the scope of Regulation (EU) No 650 / 2012 such as those relating to property rights, kinship between the deceased and the beneficiary, the deceased matrimonial regime or "property regimes of relationships deemed, under their applicable law, to have comparable effects to marriage" as it is stipulated in Article 1 paragraph $2 \mathrm{~d}$ ) of Regulation. Therefore, to determine the circle of heirs or the estate and shares related to party beneficiaries, the competent authorities shall determine under its own rules of private international law, the existence of kinship or marital problems of the patrimonial regime of the deceased ${ }^{49}$. It should be mentioned that these issues do not operate with the presumption of veracity enshrined in Article 69 paragraph 2 of the Regulation. Thus, the authorities of the destination are free to determine, in light of their own rules $^{50}$, the existence of kinship or mentioned in ECS or if matters of matrimonial settlement was done properly or not

\section{CONCLUSIONS}

It can be said that the rationale for the EMS's consecration by EU Regulation no. 650/2012 is to constitute firstly an instrument of attestation of inheritance rights resulting from a succession with elements of foreign affairs. As such, this European material instrument refers to a potential simplification of the resolution of cross-border succession. Most of the time, this potential is fully realized. However, the legal status of the European Certificate of Succession

\footnotetext{
${ }^{45}$ To be seen I-L.Vlad, Succesiuni internaţionale. Regulamentul nr. 650/2012. Tratate internaţionale în domeniu, Ed. Universul Juridic, Bucharest, 2016, page 256

${ }^{46}$ Considering that EMF cannot transmit rights to heirs who did not exist in the deceased's patrimony

${ }^{47}$ According to Recital 12: 'This Regulation should not apply to the patrimonial aspects of matrimonial property regimes, including matrimonial property regimes, as are known in some legal systems, insofar as such schemes do not deal with matters relating to successions, and patrimonial aspects of relations considered to have comparable effects to marriage. The competent authorities with regard to a certain succession under this Regulation should, however, depending on the situation, consider addressing the patrimonial aspects of the matrimonial regime, or of a similar patrimonial regime of the deceased in establishing the succession patrimony of the deceased and of those shares of the beneficiaries. "

${ }^{48}$ Until the adoption of uniform EU provisions in the field.
} 
does raise difficulties in interpreting and implementing the European legislator's provisions because of its novelty.

It is considered that making use of the European Certificate of Succession in practice will highlight its clear advantages and help to overcome the gaps that may arise in the implementation process.

In conclusion, we note that the ECS maintains the rules of the national laws of the Member States which govern the following aspects:

- who are the appointee of the inheritance and what successor statuses they have;

- the right to property and family law;

- tax issues related to succession property

\section{BIBLIOGRAPHY}

1. Veronica Stoica, Succinte considerații în legătură cu certificatul european de moștenitor, Revista de investigare a criminalității, Vol. IX, no. 1/ianuarie-iunie 2016, "Universul Juridic" Publishing House, Bucharest;

2. I-L. Vlad, Succesiuni internaționale. Regulamentul nr. 650/2012. Tratate internaționale $\hat{i n}$ domeniu, "Universul Juridic" Publishing House, Bucharest, 2016;

3. Daniela Negrilă, Moștenirea în noul Cod civil. Studii teoretice și practice. Ediția a II-a, revăzută și readăugită, "Universul Juridic" Publishing House, Bucharest, 2015;

4. C. Dorsel, "Remarques sur le certificat succesoral européen", Europe For Notaries Notaries For Europe, Training 2015-2017, JUST/2014/JTRA;

5. J. Gomes de Almeida, Le certificat successoral européen: Quelques questions, Europe For Notaries - Notaries For Europe, Training 2015-2017, JUST/2014/JTRA;

6. Ioana Olaru, Dreptul european al succesiunilor internaționale, Ghid practic, "Notarom" Publishing House, Bucharest, 2014;

7. D.A. Popescu, Ghid de drept internațional privat în materia succesiunilor, "Magic Print" Publishing House, Onești, 2014;

8. D.A. Popescu, Dreptul european al moștenirilor sau cum să traversezi râul simţind pietrele. Dreptul succesoral între trauma tradiției și perspectiva modernității. Principiile regulamentului european al succesiunilor in Revista Română de Drept Privat no. 1/2014;

9. Mariel Revillard, Drept Internațional Privat și Comunitar. Practică Notarială . Prefață de Paul Lagarde. Ediția a 6-a, "Notarom" Publishing House Bucharest, 2009;

10. Regulamentul UE no. 650/2012 al Parlamentului European și al Consiliului privind competența, legea aplicabilă, recunoașterea și executarea hotărârilor judecătorești și acceptarea și executarea actelor autentice în materie de succesiuni și privindcreareaunuicertificateuropean de moștenitor;

11. Regulamentul (CE) no. 2201/2003;

12. Convenția de la Haga din 2 octombrie 1973;

13. Legea no.36/1995 a notarilor publici și a activității notariale din România;

14. http://europarl.europa.eu/document/activities/cont/201005/20100526ATT75035/20100526 ATT75035EN.pdf - accessed at September $21^{\text {st }} 2017$;

15. https://legestart.ro/normele-ue-de-simplificare-a-succesiunilor-transfrontaliere-au-inprezent-putere-de-lege/ - accessed at September $21^{\text {st }} 2017$;

16. http://ec.europa.eu/justice/index_en.htm\#newsroom-tab - accessed at September $20^{\text {th }}$ 2017

17. http://ec.europa.eu/civiljustice/applicable_law/applicable_law_int_ro.htm - accessed at September $20^{\text {th }} 2017$;

18. http://ec.europa.eu/civiljustice/publications/docs/testaments_successions_fr.pdf - accessed at September $20^{\text {th }} 2017$;

19. http://dnoti.de/ - accessed at September $20^{\text {th }} 2017$. 